\title{
STUDI FAKTOR-FAKTOR PEMOTIVASI MANAJEMEN MELAKUKAN TAX PLANNING
}

\author{
Indrawati dan Gideon Setyo Budiwitaksono \\ Fakultas Ekonomi dan Bisnis UPN "Veteran” Jawa Timur. \\ Email: indrawati.morningdew@gmail.com dan gidboediono@gmail.com
}

\begin{abstract}
The purpose of this study is to examine the influence of Tax Policy, Tax Law, and Tax Administration on Tax Planning. Our samples consist of 20 Tax Cosultant's Clients in Surabaya.The Results of this study show that tax policy and tax administration is not a factor that can motivate management to perform tax planning. While the tax laws is a factor that can motivate management to perform tax planning. This research suggests to the Government to issue tax regulations clearly and unambiguously that there is no potential loss in tax revenue caused by the gap.
\end{abstract}

Keywords: Tax Policy, Tax Law, Tax Administration, Tax Planning.

Abstrak: Tujuan penelitian ini adalah untuk menguji pengaruh Kebijakan Pajak, Hukum Pajak, dan Administrasi Pajak Perencanaan Pajak. Sampel kami terdiri dari 20 Klien konsultan Pajak di Surabaya. Hasil penelitian ini menunjukkan bahwa kebijakan dan administrasi perpajakan bukan merupakan faktor yang dapat memotivasi manajemen untuk melakukan perencanaan pajak. Sementara undang-undang pajak merupakan faktor yang dapat memotivasi manajemen untuk melakukan perencanaan pajak. Penelitian ini menunjukkan kepada Pemerintah untuk menerbitkan peraturan pajak jelas dan tegas bahwa tidak ada potensi kerugian penerimaan pajak yang disebabkan oleh kesenjangan.

Kata kunci: Kebijakan Pajak, Hukum Pajak, Administrasi Pajak, Perencanaan Pajak.

\section{PENDAHULUAN}

Pajak memiliki manfaat sebagai sumber dana bagi pemerintah yang digunakan untuk membiayai pengeluaran-pengeluaran Negara dan sebagai alat untuk mengatur atau melaksanakan kebijakan pemerintah dalam bidang sosial Berdasarkan aspek ekonomi, pajak merupakan penerimaan Negara yang digunakan untuk mengarahkan kehidupan masyarakat menuju kesejahteraan, sedangkan berdasar dari aspek keuangan, pajak dianggap bagian yang sangat penting dalam penerimaan Negara hal ini karena kondisi keuangan Negara tidak lagi semata-mata dari penerimaan Negara berupa minyak dan gas bumi saja, tetapi lebih menjadikan pajak sebagai primadona Negara.

Alat ukur yang digunakan sebagai indikator efektif dan produktifitasnya pemungutan pajak yaitu dalam fungsinya pengumpulan penerimaan Negara berupa pajak. Kecenderungan umum dengan semakin maju suatu sistem pajak Negara, akan semakin tinggi tax ratio-nya. Pengertian Tax ratio yaitu perbandingan antara penerimaan pajak dan jumlah Produk Domestic Bruto (PDB), di Indonesia baru mencapai 11,1\% yang diharapkan tax ratio meningkat untuk setiap tahunnya, sehingga dapat tercipta kemandirian dalam pembiayaan national (Waluyo, 2008). 
Dari uraian di atas kita dapat mengetahui bahwa pengeluaran-pengeluaran rutin serta pembiayaan pembangunan national Negara kita dipengaruhi oleh besarnya pajak sebagai penerimaan Negara.Ini sebabnya pajak dikatakan sangat penting bagi Negara kita.Namun hal ini sangat bertolak belakang bagi suatu perusahaan. Bagi perusahaan, pajak merupakan beban yang akan mengurangi laba bersih. Dalam perusahaan jumlah pajak yang harus disetorkan tergantung dari besar kecilnya laba perusahaan.Semakin tinggi laba yang diperoleh perusahaan, maka semakin tinggi pula jumlah kewajiban pajak yang harus disetorkan. Membayar pajak, hampir semua orang tidak menyukainya karena dengan membayar pajak berarti "kehilangan” uang / keuntungan yang didapat dari usaha, terlebih lagi berusaha pada saat yang kritis seperti ini.

Namun yang terjadi realisasinya tidak sesuai yang diharapkan, karena dalam melaksanakan dan mematuhi kewajiban perpajakan perusahaan masih saja berusaha untuk membayar pajaknya serendah mungkin karena mereka berpendapat bahwa membayar pajak berarti mengurangi kemampuan ekonomis perusahaan wajib pajaknya. Sehingga munculah istilah Tax planning, Tax planning adalah proses mengorganisasi usaha wajib pajak atau kelompok wajib pajak sedemikian rupa sehingga utang pajaknya, baik pajak penghasilan maupun pajak-pajak lainnya, berada dalam posisi yang paling minimal, sepanjang hal ini dimungkinkan baik oleh ketentuan peraturan perundang-undangan perpajakan maupun secara komersial.

Penelitian ini bertujuan untuk menguji faktor-faktor yang memotivasi perusahaan dalam melakukan tax planning, khususnya faktor kebijakan perpajakan, undang-undang perpajakan, dan administrasi perpajakan yang terjadi di beberapa perusahaan yang melakukan Tax Planning yang juga merupakan klien dari konsultan pajak Budi Tjiptono, SE, MAk, BKP

\section{KAJIAN TEORI}

Beberapa penelitian sebelumnya yang membahasTax Planningyaitu :Fatimah Fad'aq 2013 melakukan penelitian Tentang : Analisis Faktor-Faktor Yang Mempengaruhi Panerapan Tax PlanningPada Perusahaan (Studi Kasus Pada Wajib Pajak Badan Yang Terdaftar Di Kpp Pratama Jakarta Kramat Jati). Stephanie Wibowo Dan Yenni Mangoting, 2013 Tentang: Analisis Faktor- Faktor Yang Memotivasi Manajemen Perusahaan Melakukan Tax Planning (Kpp Pratama Surabaya Sukomanunggal). Ferry Aditama, 2010 Tentang: Pengaruh Perencanaan Pajak Terhadap Manajemen Laba Pada Perusahaan Non Manufaktur Yang Terdaftar Di Bursa Efek Indonesia. Jofita Meida Kadariyanty, 2011 tentang: Analisis Faktor-Faktor Yang Memotivasi Manajemen Perusahaan Melakukan Tax Planning

Tax Planning. Secara garis besar pengertian Perencanaan Pajak (tax planning) menurut Mohammad Zain dalam bukunya manajemen perpajakan (2005:43) menyebutkan bahwa : "Perencanaan Pajak (tax planning) adalah proses mengorganisasi usaha wajib pajak atau sekelompok wajib pajak sedemikian rupa sehingga utang pajaknya, baik pajak penghasilan maupun pajak lainnya, berada dalam posisi yang paling minimal, sepanjang hal ini dimungkinkan oleh ketentuan peraturan perundang-undangan pajak”.

Adapun pengertian perencanaan pajak (tax planning) menurut Nur Hidayat dalam artikel Tax Planning Bukan Untuk Hindari Pajak (2005:1) menyebutkan bahwa : “ 
perencanaan pajak (tax planning) adalah upaya menekan jumlah kewajiban pajak dengan cara legal ".

Dari kedua definisi diatas dapat disimpulkan bahwa perencanaan pajak adalah upaya untuk mengatur pembayaran pajak atau meminimalkan kewajiban pajak dengan tidak melanggar peraturan perundang-undangan yang berlaku, agar pajak yang dibayar tidak lebih dari jumlah yang seharusnya.

Pada umumnya, perencanaan pajak (tax planning) merujuk kepada proses merekayasa usaha dan transaksi wajib pajak agar utang pajak berada dalam jumlah yang minimal, tetapi masih dalam bingkai peraturan perpajakan.

Suatu perencanaan pajak yang tepat akan menghasilkan beban pajak minimal yang merupakan hasil dari perbuatan penghematan pajak atau penghindaran pajak, bukan karena penyelundupan pajak yang tidak berdasarkan pada peraturan perundang-undangan perpajakan.

Kebijakan perpajakan dan Tax Planning. Kebijakan perpajakan (tax policy) merupakan alternatif dari berbagai sasaran yang hendak dituju dalam sistem perpajakan yang meliputi prosedur perpajakan, objek pajak, dan pengurang objek pajak. Pada saat ini, sistem pembayaran pajak yang berlaku di Indonesia dilandasi oleh sistem pemungutan di mana wajib pajak pribadi ataupun badan diperbolehkan untuk menghitung, menghitungkan, membayar, dan menyetor sendiri besarnya pajak yang harus disetorkan (self assessment system).self assessment system merupakan salah satu faktor yang dapat memotivasi wajib pajak melakukan perencanaan pajak. Dengan adanya kepercayaan yang diberikan kepada wajib pajak, maka hal ini membuat wajib pajak termotivasi untuk merencanakan pajaknya.Dengan pengetahuan wajib pajak untuk melakukan perencanaan pajak dalam meminimalisasi beban pajak yang harus dibayar.(Tanuwiardi, 2006).

Hasil penelitian dariStephanie Wibowo dan Yenni Mangoting(2013) menyimpulkan bahwa Kebijakan perpajakan berpengaruh postif, artinya pengetahuan tentang kebijakan perpajakan diukur dengan menggunakan alternatif- alternatif yang ada di dalam kebijakan perpajakan. Semakin tinggi pengetahuan manajemen perusahaan tentang alternatif yang dapat digunakan di dalam kebijakan perpajakan, maka semakin tinggi pula manajemen perusahaan melakukan tax planning. Berdasarkan teori dan dari hasil penelitian sebelumnya, maka menghasilkan konsep pemikiran bahwa kebijakan perpajakan merupakan salah satu faktor yang dapat mempengaruhi motivasi manajemen perusahaan dalam melakukan tax planning .

H1. Kebijakan Perpajakan berpengaruh terhadap motivasi Tax Planning

Undang-undang perpajakan dan Tax Planning. Undang-undang pajak merupakan kumpulan peraturan-peraturan yang mengatur masalah perpajakan. Pada kenyataannya di manapun tidak ada peraturan perpajakan yang mengatur setiap permasalahan secara sempurna. Oleh karena ketidak sempurnaan tersebut, maka wajib pajak melakukan tax planning dengan cara mendeteksi cacat teoritis dalam ketentuan peraturan perundangundangan perpajakan tersebut. Dengan melaksanakan tax planning dengan memanfaatkan celah-celah dari peraturan perundang-undangan perpajakan tersebut.

Hasil penelitian dari Stephanie Wibowo dan Yenni Mangoting(2013)menyimpulkan bahwa Undang- undang perpajakan berpengaruh positif, artinya celah- celah yang terdapat di dalam undang- undang perpajakan tersebut yang digunakan oleh manajemen perusahaan untuk melakukan tax planning. Semakin banyak celah- celah yang terdapat di 
dalam undang- undang perpajakan, maka semakin tinggi pula kesempatan manajemen perusahaan untuk merencanakan pajak dengan baik.

Berdasarkan teori dan dari hasil penelitian sebelumnya, maka menghasilkan konsep pemikiran bahwa Undang-undang perpajakan merupakan salah satu faktor yang dapat mempengaruhi motivasi manajemen perusahaan dalam melakukan tax planning .

H2. Undang-undang Perpajakan berpengaruh terhadap motivasi Tax Planning

Administrasi perpajakan dan Tax Planning. Hal yang mendorong wajib pajak untuk melaksanakan perencanaan pajak dengan baik adalah agar terhindar dari sanksi administrasi maupun sanksi pidana.Hal ini dikenakan adanya perbedaan penafsiran antara fiskus dan wajib pajak akibat dari terlalu luasnya peraturan perpajakan yang berlaku.Pada umumnya wajib pajak tidak mengharapkan adanya sanksi-sanksi tersebut karena dengan terkenanya saknsi tersebut membuat perusahaan harus membayar sejumlah uang untuk denda, hal ini merpakan pemborosan bagi wajib pajak.

Hasil penelitian dari Stephanie Wibowo dan Yenni Mangoting (2013)menyimpulkan bahwa Administrasi perpajakan berpengaruh positif, artinya manajemen perusahaan melakukan administrasi perpajakan dengan baik agar terhindar dari sanksi yang dapat menimbulkan pemborosan dana perusahaan. Hal tersebut mendorong perusahaan untuk melakukan tax planning dengan baik. Hasil penelitian menyimpulkan bahwa semakin baik administrasi perpajakan yang dilakukan manajemen perusahaan untuk menghindari adanya sanksi, maka semakin baik manajemen perusahaan melakukan tax planning. Berdasarkan teori dan dari hasil penelitian sebelumnya, maka menghasilkan konsep pemikiran bahwa administrasi perpajakan merupakan salah satu faktor yang dapat mempengaruhi motivasi manajemen perusahaan dalam melakukan tax planning.

H3. Administrasi Perpajakan berpengaruh terhadap motivasi Tax Planning.

\section{METODE}

Obyek yang digunakan dalam penelitian ini adalah motivasi yang melatarbelakangi manajemen perusahaan dalam melakukanPerencanaan Pajak (Tax Planning) studi dilakukan di beberapa perusahaan yang juga merupakan Klien dari konsultan pajak Budi Tjiptono, SE, MAk, BKP yang berada di Surabaya yang berkaitan dengan kebijakan perpajakan, undang-undang perpajakan, dan administrasi perpajakan untuk diteliti pengaruhnya terhadap Tax Planning.

Sampel penelitian ini berjumlah 20 orang.Jenis data yang digunakan yaitu data primer yang berasal dari jawaban kuisioner yang disebar kepada manajemen perusahaan yaitu bagian perpajakan dan administrasi.Teknik pengambilan sampel menggunakan caraProbability sampling dengan menggunakan teknik jenuh/sensus yaitu teknik penentuan sampel bila semua anggota populasi digunakan sebagai sampel

Uji instrument yang digunakan adalah uji validitas dan reliabilitas. Valid atau tidaknya alat ukur tersebut dapat diuji dengan mengkorelasikan antara skor total yang diperoleh dari penjumlahan semua skor pertanyaan ditunjukkan dengan taraf signifikasi $<0,05(\alpha=5 \%)$, maka dapat dikatakan bahwa alat pengukur tersebut mempunyai validitas (Sumarsono, 2004:31). Untuk menguji reliabilitas jika croncbach's alpha > 0,60 maka instrument penelitian tersebut dapat dikatakan reliabel. Beberapa asumsi klasik yang digunakan yaitu uji normalitas, uji multikolinieritas dan uji heteroskodasitas.Penelitian ini enggunakan teknik analissi regresi linier berganda. Model regresi sebagai berkut: 
Keterangan:

$$
Y=\alpha+\beta_{1} X_{1}+\beta_{2} X_{2}+\beta_{3} X_{3}+e
$$

$\mathrm{Y}=$ Memotivasi dilakukannya Tax planning; $\beta_{0}=$ Konstanta; $\beta_{1}, \beta_{2}, \beta_{3}=$ Koefisien Regresi; $\mathrm{X} 1$ = Kebijakan Perpajakan; $\quad \mathrm{X} 2=$ Undang-Undang Perpajakan; $\mathrm{X} 3=$ Administrasi Perpajakn

Uji hipotesis penelitian ini menggunakan uji kesesuaian model dan uji parsial

\section{HASIL DAN PEMBAHASAN}

Analisis Data. Dalam penelitian ini diperoleh melalui survey lapangan dengan menyebarkan kuisioner kepada manajemen perusahaan khususnya bagian perpajakan dan keuangan.Peneliti telah menyebar20 kuisioner dengan tingkat pengembalian 100\%.

Dari hasil Uji Validitas tahap pertama menunjukan ada beberapa pernyataan yang tidak valid namun setelah melakukan uji validitas tahap kedua menunjukkan masing masing item pernyataan mempunyai nilai signifikasi lebih kecil dari 0,005 $(<0,005)$, dan sesuai dengan dasar analisis yang digunakan, hal ini berarti bahwa seluruh butir atau item pertanyaan kuisioner di tahap kedua tersebut seluruhnya valid dan dapat digunakan dalam penelitian. Hasil reliabilitas menunjukkan besarnya nilai Cronbach Alpha pada seluruh variabel lebih besar dari 0,60 dan sesuai dengan dasar analisi yang digunakan, hal ini berarti bahwa seluruh variabel yang digunakan dalam penelitan seluruhnya reliabel dan dapat digunakan dalam penelitian.

Beberapa asumsi klasik yang digunkana antara lain:

Tabel 1. Uji Normalitas

One-Sample Kolmogorov-Smirnov Test

\begin{tabular}{llr}
\hline $\mathrm{N}$ & & Unstandardized Residual \\
\hline \multirow{2}{*}{ Normal Parameters ${ }^{\mathrm{a}, \mathrm{b}}$} & Mean & 20 \\
& Std. Deviation & .0000000 \\
& Absolute & 1.22954217 \\
Most Extreme Differences & Positive & .192 \\
& Negative & .192 \\
Kolmogorov-Smirnov Z & & -.137 \\
Asymp. Sig. (2-tailed) & & .860 \\
\hline
\end{tabular}

a. Test distribution is normal

b. Calculated from data

Hasil uji normalitas menunjukkan besarnya nilai Probabilitas Asymp sig (2-tailed) sebesar 0,450 lebih besar dari 5\% $(0,05)$ dan sesuai dengan dasar analisis, hal ini berarti bahwa data adalah berdistribusi normal, sehingga seluruh variabel digunakan dalam penelitian ini baik variabel $\mathrm{X}_{1}, \mathrm{X}_{2}, \mathrm{X}_{3}$, dan $\mathrm{Y}$ dapat digunakan dalam penelitian. 
Tabel 2. Uji Multikolinieritas

\begin{tabular}{|c|c|c|c|}
\hline \multicolumn{2}{|c|}{ Model } & \multicolumn{2}{|c|}{ Collinearity Statistics } \\
\hline & & Tolerance & VIF \\
\hline \multirow{4}{*}{1} & (Constant) & & \\
\hline & Kebijakan perpajakan & 876 & 1,142 \\
\hline & Undang-undang perpajakan & ,824 & 1,213 \\
\hline & Administrasi perpajakan & ,916 & 1,091 \\
\hline
\end{tabular}

a. Dependent Variabel: Tax Planning

Hasil uji multikolinieritas menunjukkan seluru variabel bebas (X) yang digunakan dalam penelitian ini baik $\mathrm{X}_{1}, \mathrm{X}_{2}$, dan $\mathrm{X}_{3}$ mempunyai nilai VIF (Variance Influence Factor) lebih kecil dari 10, dan sesuai dengan dasar analisis yang digunakan, hal ini berarti bahwa dalam persamaan regresi tidak ditemukan adanya korelasi antar variabel bebas atau bebas multikolinieritas.

Tabel 3. Uji Heteroskodasitas Corelations

\begin{tabular}{|c|c|c|c|c|c|}
\hline & & $\begin{array}{l}\text { Kebijakan } \\
\text { Perpajkan }\end{array}$ & $\begin{array}{l}\text { Undang - } \\
\text { undang } \\
\text { Perpajakan }\end{array}$ & $\begin{array}{l}\text { Administ } \\
\text { rasiPerpa } \\
\text { jakan }\end{array}$ & $\begin{array}{l}\text { Unstandar } \\
\text { dized } \\
\text { Residual }\end{array}$ \\
\hline \multirow{4}{*}{ KebijakanPerpajkan } & Correlation & 1.000 & .204 & -.099 & -.184 \\
\hline & Coefficient & & & & \\
\hline & Sig. (2-tailed) & & .388 & .679 & 438 \\
\hline & $\mathrm{N}$ & 20 & 20 & 20 & 20 \\
\hline \multirow{4}{*}{$\begin{array}{l}\text { Undang - } \\
\text { undangPerpajakan }\end{array}$} & Correlation & .204 & 1.000 & .254 & -.014 \\
\hline & Coefficient & & & & \\
\hline & Sig. (2-tailed) & .388 & & .280 & .955 \\
\hline & $\mathrm{N}$ & 20 & 20 & 20 & 20 \\
\hline & Correlation & -.099 & .254 & 1.000 & .236 \\
\hline Administrasi & Coefficient & & & & \\
\hline \multirow[t]{3}{*}{ Perpajakan } & Sig. (2-tailed) & .679 & .280 & . & .317 \\
\hline & $\mathrm{N}$ & 20 & 20 & 20 & 20 \\
\hline & Correlation & -.184 & -.014 & .236 & 1.000 \\
\hline Unstandardized & Coefficient & & & & \\
\hline \multirow[t]{2}{*}{ Residual } & Sig. (2-tailed) & .438 & .955 & .317 & . \\
\hline & $\mathrm{N}$ & 20 & 20 & 20 & 20 \\
\hline
\end{tabular}

Hasil uji heteroskodasitas menunjukkan bahwa seluruh variabel bebas (X) yang digunakan dalam penelitian ini $\mathrm{X}_{1}, \mathrm{X}_{2}$, dan $\mathrm{X}_{3}$, mempunyai nilai probabilitas Sig (2tailed) lebih besar dari 5\% dan sesuai dengan dasar analisi yang digunakan, hal ini berarti bahwa dalam model regresi tidak terjadi ketidaksamaan varience dari residual satu pengamatan ke pengamatan lainnya atau Bebas Heteroskodasitas. 
Tabel 4. Hasil Pendugaan Parameter Regresi Linier Berganda

\begin{tabular}{llcc}
\hline & & \multicolumn{2}{c}{ Unstandardized Coefficients } \\
\cline { 3 - 4 } Model & & B & Std. Error \\
\hline 1 & (Constant) & 2,935 & 1,846 \\
& Kebijakan Perpajakan &,- 046 &, 094 \\
& Undang-undang Perpajakan &, 154 &, 068 \\
& Administrasi Perpajakan &,- 127 &, 214 \\
\hline
\end{tabular}

Sumber : Data Diolah, 2015

Berdasarkan tabel 4. maka model persamaan regresi sebagi berikut:

$$
\mathrm{Y}=2,935-0,046 \mathrm{X}_{1}+0,154 \mathrm{X}_{2}-0,127 \mathrm{X}_{3}
$$

Pengujian Hipótesis. Hasil pengujian hipotesis didasarkan dapat analisis regresi linear berganda yang ditunjukkan pada tabel berikut ini.

Tabel 5. Hasil Analisis Uji Kesesuaian Model

ANOVA $^{\mathrm{a}}$

\begin{tabular}{llccccc}
\hline Model & & Sum of Squares & df & Mean Square & F & Sig. \\
\hline \multirow{3}{*}{1} & Regression & 9.476 & 3 & 3.159 & 1.760 & $.010^{\mathrm{b}}$ \\
& Residual & 28.724 & 16 & 1.795 & & \\
& Total & 38.200 & 19 & & & \\
\hline
\end{tabular}

a. Dependent Variabel: Tax Planning

b. Predictors: (Constant, Administrasi Perpajakan, Kebijakan Perpajakan, Undang-undang Perpajakan

Berdasarkan pada Tabel 5 dapat diketahui bahwa besarnya nilai $\mathrm{F}$ hitung sebesar 1,760 dengan tingkat signifikasi sebesar 0,010 (lebih kecil dari 0,05), sehingga $\mathrm{H}_{0}$ ditolak dan $\mathrm{H}_{1}$ diterima, hal ini menunjukkan bahwa model regresi yang dihasilkan cocok guna melihat pengaruh dari Kebijakan Perpajakan, Undang-undang Perpajakan dan Administrasi Perpajajakan terhadap Tax Planning.

Tabel 6. Hasil Analisis Variabel Bebas Terhadap Variabel Terikat

\begin{tabular}{|c|c|c|c|c|}
\hline \multirow[b]{2}{*}{ Variabel } & \multirow[b]{2}{*}{ thit } & \multicolumn{3}{|c|}{ Correlation } \\
\hline & & Sig & Partial (r) & $\left(r^{2}\right) \times 100 \%$ \\
\hline Kebijakan Perpajakan $\left(\mathrm{X}_{1}\right)$ & $-0,489$ & 0,631 & $-0,121$ & 1,46 \\
\hline Undang-undang Perpajakan $\left(\mathrm{X}_{2}\right)$ & 2,275 & 0,037 & 0,494 & 24,4 \\
\hline Administrasi Perpajakan $\left(\mathrm{X}_{3}\right)$ & $-0,135$ & 0,560 & $-0,147$ & 2,16 \\
\hline
\end{tabular}

Pengaruh Kebijakan Perpajakan terhadap Tax Planning. Berdasrkan Tabel 6 dapat diketahui besarnya nilai t hitung sebesar $-0,489$, dengan tingkat signifikasi sebesar 0,631 $(>0,05)$, sesuai dengan ketentuan yang telah ditetapkan, maka hal ini berarti Kebijakan Perpajakan secara parsial tidak berpengaruh signifikan terhadap Tax Planning. Sedangkan untuk mengetahui besarnya pengaruh yang diberikan variabel Kebijakan Perpajakan terhadap Tax Planning, dapat dilihat pada kolom Correlation Partial $(r)^{2}=(-0,121)=$ 
0,0146 yang berarti bahwa variabel Kebijakan Perpajakan mampu mempengaruhi variabel Tax Planning sebesar 0,0146 atau 1,46 \%.

Pengaruh Undang-undang Perpajakan terhadap Tax Planning. Berdasrkan tabel 6 dapat diketahui besarnya nilai t hitung sebesar 2,275, dengan tingkat signifikasi sebesar $0,037(<0,05)$, sesuai dengan ketentuan yang telah ditetapkan, maka hal ini berarti Undang-undang Perpajakan secara parsial berpengaruh signifikan terhadap Tax Planing. Sedangkan untuk mengetahui besarnya pengaruh yang diberikan variabel Undang-undang Perpajakan terhadap Tax Planing, dapat dilihat pada kolom Correlation Partial $(\mathrm{r})^{2}=$ $0,494)=0,244$ yang berarti bahwa variabel Undang-undang Perpajakan mampu mempengaruhi variabel Tax Planing sebesar 0,244 atau 24,4\%.

Pengaruh Administrasi Perpajakan terhadap Tax Planing. Berdasrkan Tabel 6 dapat diketahui besarnya nilai t hitung sebesar $-0,135$, dengan tingkat signifikasi sebesar 0,560 $(>0,05)$, sesuai dengan ketentuan yang telah ditetapkan, maka hal ini berarti Administrasi Perpajakan secara parsial tidak berpengaruh signifikan terhadap Tax Planing Sedangkan untuk mengetahui besarnya pengaruh yang diberikan variabel Administrasi Perpajakan terhadap Tax Planing, dapat dilihat pada kolom Correlation Partial $(r)^{2}=(-0,147)=$ 0,0216 yang berarti bahwa variabel Administrasi Perpajakan mampu mempengaruhi variabel Tax Planing sebesar 0,0216 atau 2,16\%.

Hasil pengujian faktor Kebijakan perpajakan menyatakan secara parsial tidak berpengaruh terhadap Tax Planning, hal ini menunjukkan bahwa perubahan yang terjadi pada Kebijakan perpajakan akan tidak mempengaruhi Tax Planning. Dan sesuai dengan penelitian menunjukkan pengaruh negatif, artinya semakin ketat kebijakan perpajakan yang berlaku maka semakin tidak memotivasi manajemen perusahaan melakukan tax planning.hal ini tidak sejalan dengan penelitian Sally Tanjung (2013) dan Stephanie Wibowo da Yenni (2013) yang menyatakan bahwa kebijakan perpajakan berpengaruh secara positif serta berpengaruh secara signifikan.

Hasil pengujian faktor Undang- undang perpajakan menyatakan secara parsial berpengaruh terhadap Tax Planning, hal ini menunjukkan bahwa perubahan yang terjadi pada Undang- undang perpajakan akan mempengaruhi Tax Planning. Dan sesuai dengan penelitian menunjukkan pengaruh positif, artinya semakin terinci atau detail undangundang perpajakan maka semakin tinggi motivasi manajemen perusahaan untuk melakukan Tax Planning dengan baik, hal ini sejalan dengan penelitian Sally Tanjung (2013) dan Stephanie Wibowo da Yenni (2013) yang menyatakan bahwa undang-undang perpajakan berpengaruh secara positif serta berpengaruh secara signifikan.

Hasil pengujian faktor Administrasi perpajakan menyatakan secara parsial juga tidak berpengaruh terhadap Tax Planning, hal ini menunjukkan bahwa perubahan yang terjadi pada Administrasi perpajakantidak akan mempengaruhi Tax Planning. Dan sesuai dengan penelitian menunjukkan pengaruh negatif, artinya bahwa semakin taat administrasi perpajakan yang dilakukan manajemen perusahaan untuk menghindari adanya sanksi, maka semakin rendah kecenderungan manajemen perusahaan termotivasi melakukan tax planning.hal ini juga sama dengan penelitian terhadap penelitian Kebijakan perpajakan yang sama sekali tidak sejalan dengan penelitian Sally Tanjung (2013) dan Stephanie Wibowo da Yenni (2013) yang menyatakan bahwa administrasi perpajakan berpengaruh secara positif serta berpengaruh secara signifikan. 


\section{PENUTUP}

Simpulan. (1) Kebijakan Perpajakan tidak berpengaruh terhadap Tax Planning. artinya semakin ketat kebijakan perpajakan yang berlaku maka semakin tidak memotivasi manajemen perusahaan melakukan tax planning; (2) Undang-undang Perpajakan berpengaruh terhadap Tax Planning. Artinya semakin detail atau terinci undang- undang perpajakan tersebut maka semakin tinggi motivasi manajemen perusahaan untuk melakukan Tax Planning dengan baik; (3) Administrasi perpajakan juga tidak berpengaruh terhadap TaxPlanning. bahwa semakin taat administrasi perpajakan yang dilakukan manajemen perusahaan untuk menghindari adanya sanksi, maka semakin rendah kecenderungan manajemen perusahaan termotivasi melakukan tax planning.

Saran. (1) Adanya penambahan variabel-variabel lain yang mempengaruhi wajib pajak melakukan perencanaan pajak (tax planning) untuk penelitian selanjutnya; (2) Pemerintah disarankan membuat peraturan perpajakan yang jelas dan tegas sehingga tidak ada potensi kerugian dalam penerimaan pajak yang diakibatkan oleh celah-celah atau loopholes; (3) Negara wajib mengelola hasil penerimaan pajak dengan lebih baik seperti diberantasnya tindakan korupsi petugas pajak. Selain itu, para petugas pajak sendiri disarankan untuk meningkatkan kualitasnya dalam memberikan layanan kepada wajib pajak, sehingga melalui pelayanan yang diberikan dapat mendorong wajib pajak untuk melakukan pembayaran pajaknya.

\section{DAFTAR RUJUKAN}

Aditama, Ferry, (2010) “Pengaruh Perencanaan Pajak Terhadap Manajemen Laba Pada Perusahaan Non Manufaktur yang Terdaftar di Bursa Efek Indonesia”.

Al Huzein, Syahri, (2002) Aplikasi Statistik Praktis dengan SPSS 10 for windows, Yogyakarta: J\&J Learning

Algifran, (2000) Analisis Regresi Teori, kasus,dan solusi, Yogyakarta: BPFE

Asnawi, S, (2002) Teori Motivasi, Jakarta,Studia Press

Chandra, Dwi, (2006) Analisis Faktor-faktor yang Memotivasi Manajemen Perusahaan Melakukan Tax Planning (study beberapa perusahaan di daerah Margomulyo). Universitas Pembangunan Nasional

Erly, Suandy, (2006) Perencanaan Pajak (Edisi 3), Jakarta: Salemba Empat

Faisal, Gatot, (2009) How To be A Smarter Tax Payer, Jakarta: Grasindo

Fatimah, (2013) Analisis Faktor-faktor yang Mempengaruhi Penerapan Tax Planning pada Perusahaan, Jakarta

Ghozali, Imam, (2009) Aplikasi Analisis Multivarrate dengan Program SPSS, Semarang: Universitas Diponegoro

Hidayat, Nur, (2000) “Menelusuri Tax Planning dalam Kerangka Undang-undang”, Jurnal Perpajakan Indonesia

Lumbantoruan, Sophar, (1996) Akuntansi Pajak, Edisi Revisi, Jakarta:Grasindo

Mardiasmoro. (2009) Perpajakan edisi Revisi 2009, Yogyakarta: Andi

Meida, Jofita, (2011) Analisis Faktor-Faktor Yang Memotivasi Manajemen Perusahaan Melakukan TaxPlanning, UPN Veteran Jatim, Surabaya

Nazir, Mohammad, (2005) Metode Penelitian, Bogor: Ghalia Indonesia

Sugiyono, (2006) Metode Penelitian Administrasi, Bandung: Alfabeta 
Sulaiman, wahid, (2004) Analisis Regrasi Menggunakan SPSS, Yogyakarta: Andi Offset Sumarsono. (2004) Metode Penelitian Akuntansi, Surabaya, Penerbit Fakultas Ekonomi UPN “Veteran”Jawa Timur

Tanjung, Sally, (2013) "Pengaruh Kebijakan Perpajakan, Peraturan Perpajakan, Sanksi Administrasi dan Pemeriksaan Pajak, Persepsi Wajib Pajak Terhadap Perencanaan Pajak Wajib Pajak Orang Pribadi yang Merupakan Klien dari Kantor Konsultan Pajak X”,Tax and Accounting Review Vol. 1 No. 1

Tanuwiardi, Martha, (2006) Analisis Faktor-faktor yang Memotivasi Manajemen Perusahaan Melakukan Tax Planning daerah SIER. Universitas Kristen Petra

Umar, husein, (2004) Metode Penelitian untuk Skripsi dan Tesis Bisnis, Jakarta: Rajawali Pers

Undang-undang no.28 tahun 2007 tentang perubahan ketiga atas Undang-undang No.6 Tahun 1983 tentang Ketentuan Umum dan Tata Cara Perpajakan

Undang-undang no.36 tahun 2008 tentang perubahan keempat atas Undang-undang No.7

Tahun 1983 tentang Pajak Penghasilan

Undang-undang no.42 tahun 2009 tentang perubahan ketiga atas Undang-undang No.8

Tahun 1983 tentang Pajak Pertambahan Nilai Barang dan Pajak Penjualan atas

Barang Mewah

Waluyo, (2008) Perpajakan Indonesia, Jakarta: Salemba Empat

Weiner (1990) http://kasyfilaziz15.blogspot.in/2013/11/motivasi.html?m=1

Wibowo, Stephanie, (2013) “Analisis Faktor-faktor yang Memotivasi Manajemen

Perusahaan Melakukan Tax Planning”, Tax and Accounting Review Vol. 1 (1)

Zain, Mohammad, (2005) Manajemen Pajak, Jakarta: Salemba Empat 